\title{
Clinical significance of stanniocalcin-1 detected in peripheral blood and bone marrow of esophageal squamous cell carcinoma patients
}

Haizhu Song ${ }^{1}$, Biao $\mathrm{Xu}^{2}$ and Jun $\mathrm{Yi}^{\mathrm{i}^{*}}$

\begin{abstract}
Background: Stanniocalcin-1 (STC-1) is a potential marker of disseminated tumor cells (DTCs). The aim of this study was to examine STC-1 expression in peripheral blood (PB) and bone marrow (BM) of esophageal squamous cell carcinoma (ESCC) patients, and to evaluate its clinical significance.

Methods: A total of 85 ESCC patients treated with radical resection were enrolled in this study. Immunohistochemistry was used to detect STC-1 protein expression in ESCC tissues. Nested RT-PCR was used to detect STC-1 mRNA expression in PB and BM.

Results: There were 71 cases (83.5\%) showed a higher level of STC-1 protein expression in tumor tissues than in adjacent normal tissues $(P<0.001)$. Furthermore, the frequencies of STC-1 mRNA expression detected in PB and BM were $37.6 \%$ (32/85) and 21.2\% (18/85), respectively, and together increased sensitivity to $48.2 \%$ (41/85), which was much higher than that in patients with benign esophageal disease $(5.0 \%, 2 / 40, P<0.001)$. In addition, STC-1 mRNA expression either in PB or BM was correlated with lymph metastasis, advanced stage and adverse 2-year progression free survival (PFS). In a multivariate analysis using the Cox proportional hazard model, STC-1 expression in PB and/or BM was an independent unfavorable prognostic factor for ESCC, apart from lymph metastasis and clinical stage.

Conclusions: STC-1 mRNA expression is a reliable marker for detection of DTCs in PB and BM of ESCC patients, and STC-1-positive DTCs may be a promising tool for diagnosis and prognosis assessment in ESCC.
\end{abstract}

Keywords: Esophageal squamous cell carcinoma, Stanniocalcin-1, Disseminated tumor cells, Peripheral blood, Bone marrow, Micrometastasis, Prognosis

\section{Background}

Esophageal squamous cell carcinoma (ESCC) comprises the majority of esophageal cancer in China and it is characterized by a high incidence and mortality rate [1]. Even though this disease is surgically curable in the early stages, patients often suffer asymptomatic metastasis that is associated with a high mortality [2]. Evidences have shown that, cancer cells from the original region may disseminate into the peripheral blood (PB) or bone marrow (BM) in the early stage and survive without clinical representation as micrometastasis, an important initial step for recurrence and distant metastases [3,4]. Thus, it

\footnotetext{
* Correspondence: njyijun@163.com

${ }^{2}$ Department of Cardiothoracic Surgery, Jinling Hospital, 305 East Zhongshan Road, Nanjing, 210002, P.R. China

Full list of author information is available at the end of the article
}

is clearly imperative to monitor these disseminated tumor cells (DTCs), which may contribute to improved diagnosis or prognosis and therefore more appropriate treatments.

As a result of the removal by immune system, very few DTCs exist and are undetected by normal methods. So far many different techniques have been applied for enriching and detecting DTCs, but the most commonly used is conventional reverse-transcriptase polymerase chain reaction (RT-PCR), because of the high degree of sensitivity and specificity, allowing the detection of one malignant cell among $10^{6} \sim 10^{7}$ monocytes [5]. Accordingly, an appropriate marker used in RT-PCR would be of a paramount importance, which should be expressed only in tumor cells, but not in normal cells. Previous

\section{Biomed Central}


studies have shown stanniocalcin-1 (STC-1) may be a promising tumor marker, for its high expression level in various of malignancies including ESCC, as compared with adjacent normal tissues [6-8]. Therefore, we determined the STC-1 mRNA expression using nested RTPCR in PB and BM from ESCC patients treated with radical resection, and their associations with clinicopathological features and 2 year progression-free survival (PFS) were further eval

\section{Methods}

\section{Study population}

This study enrolled 85 ESCC patients treated with radical resection at Jinling Hospital from July 2006 to July 2008. Patients consisted of 54 males and 31 females, with a median age of 62 (range, 44-83) years. Tumor stage was conducted according to the $7^{\text {th }}$ edition of the TNM staging system of the International Union Against Cancer [9], and patients were at stages I $(\mathrm{n}=18)$, II $(\mathrm{n}=25)$, III $(\mathrm{n}=33)$ and IV $(\mathrm{n}=9$, supraclavicular or paraaortic lymph nodes metastasis). Cellular differentiation was graded according to the WHO grading system. Ethical approval was obtained from the hospital and informed consent was obtained from all patients prior to sample examination. Clinical follow-up data were available for all the patients. For each patient, $10 \mathrm{~mL}$ PB before surgery was collected, and PB mononuclear cells were isolated using Lymphocyte separation medium (Sigma, St. Louis, USA) according to the manufacturer's protocol. Also, $5-10 \mathrm{~mL}$ of BM was aspirated from ribs during surgical treatment, and mononuclear cells were isolated from BM by Ficoll gradient centrifugation and then aliquoted to isolate RNA. PB and BM samples from 40 patients with benign esophageal disease were also collected.

\section{Immunohistochemical staining}

Formalin-fixed, paraffin-embedded samples used for immunohistochemistry were sectioned at $2 \mu \mathrm{m}$ thickness. Sections were deparaffinized using xylene, dehydrated by gradient ethanol, and then rehydrated with deionized water. Heat-mediated antigen retrieval was run by autoclave treatment $\left(120^{\circ} \mathrm{C}\right.$ for $2 \mathrm{~min}$ in $1 \mathrm{mmol} / \mathrm{L}$ ethylenediaminetetraacetic acid [EDTA], $\mathrm{pH}$ of 8.0) and then followed by cooling at room temperature. Incubation with a polyclonal goat anti-STC-1 antibody (diluted 1:200, Santa Cruz Biotechnology, CA, USA) was performed overnight at $4^{\circ} \mathrm{C}$. After washing with phosphate-buffered saline (PBS), sections were then incubated with donkey anti-goat secondary antibody (Santa Cruz) for $30 \mathrm{~min}$ at room temperature. Coloration was performed with 3,3-diaminobenzidine. Nuclei were counterstained with hematoxylin. PBS was used as a negative control for the staining reactions. Immunostaining results were evaluated independently by 3 pathologists. The percentage of positive cells was rated as follows: 0 score for $0-5 \%, 1$ score for $6-25 \%, 2$ scores for $26-50 \%$, and 3 scores for more than $50 \%$. The staining intensity was rated as follows: 0 score for no staining, 1 score for weak staining, 2 scores for moderate staining, and 3 scores for strong staining [10]. The scores from the percentage and intensity were added to an overall score, and the expression of STC-1 protein in ESCC with an overall score of 0 was designated as 'negative', 1-2 was designated as 'low', 3-4 was designated as 'moderate' and 5-6 was designated as 'high'.

\section{Nested RT-PCR}

Total RNA in mononuclear cells was extracted by Trizol reagent (Invitrogen, Carlsbad, CA, USA) and RNA concentration was measured by spectrophotometer (BioPhotometer, Eppendorf, Hamburg, German). Approximately $1 \mu \mathrm{g}$ of total RNA was used for cDNA synthesis using a PrimeScript 1 st Strand cDNA Synthesis Kit (TaKaRa, Shiga, Japan). PCR reaction was performed in a $25 \mu \mathrm{l}$ volume comprised of $5 \mu \mathrm{l}$ of DNA template, $10 \times$ Buffer, $0.15 \mathrm{mM}$ dNTPs, $0.1 \mathrm{mM}$ of each primer and $0.5 \mathrm{U}$ of Ex Taq Hot Start Version (Takara). Primer sequences and amplification conditions are listed in Table 1 and have been described elsewhere [11]. PCR products were identified on a $2 \%$ agarose gel containing ethidium bromide. A resected ESCC tumor tissue and water blank were used as positive and negative control, respectively.

\section{Statistical analysis}

Statistical tests were carried out using SPSS version 16.0 (SPSS Inc., Chicago, IL, USA). The differential expressions of STC-1 between tumor and adjacent normal specimens were calculated with Student's t-test. Differences in frequency were assessed by Chi-square test or Fisher's exact test. Overall survival curves were calculated using the Kaplan-Meier method and compared by log-rank testing. Multivariate Cox proportional hazard models were used to define the potential prognostic significance of individual parameter. $P<0.05$ was taken as statistically significant.

\section{Results}

\section{STC-1 protein expression profiles in ESCC tissue}

We determined STC-1 protein expression in 85 pairs of ESCC and matched normal tissues by immunohistochemical staining. The representative immunohistochemical results are shown in Figure 1(A-D). In total, there were 71 cases $(83.5 \%)$ showed a higher level of STC-1 protein expression in tumor tissues than in normal tissues, and the average immunostaining scores in tumor tissues were $3.08 \pm 1.81$ while in normal tissues was 
Table 1 List of the nested PCR primers

\begin{tabular}{llcc}
\hline Primers & \multicolumn{1}{c}{ Sequences (5'-3') } & Products & \multicolumn{1}{c}{ PCR conditions } \\
\hline STC-1 (outer) & CTTCACTCAAGCCAGGAGAGGGAAAGAGGAAA & $890 \mathrm{bp}$ & $94^{\circ} \mathrm{C}$ for $30 \mathrm{~s}, 62^{\circ} \mathrm{C}$ for $30 \mathrm{~s}, 72^{\circ} \mathrm{C}$ for 1 min, 40 cycles \\
& TGGTGTGTCAACACCCCTAAAATGATA & \\
STC-1 (inner) & GTGGCGGCTCAAAACTCAGCTGAA & $645 \mathrm{bp}$ & $94^{\circ} \mathrm{C}$ for $30 \mathrm{~s}, 60^{\circ} \mathrm{C}$ for $30 \mathrm{~s}, 72^{\circ} \mathrm{C}$ for 1 min, 40 cycles \\
& TTATGCACTCTCATGGGATGTGCGT & & \\
$\beta$-actin & CCCTGGACTTCGAGCAAGAGAT & $531 \mathrm{bp}$ & $94^{\circ} \mathrm{C}$ for $30 \mathrm{~s}, 55^{\circ} \mathrm{C}$ for $30 \mathrm{~s}, 72^{\circ} \mathrm{C}$ for 1 min, 35 cycles \\
& GTITTCTGCGCAAGTTAGG & & \\
\hline
\end{tabular}

$1.05 \pm 1.08$ (Figure 1E, $P<0.001$ ). Moreover, distribution of immunostaining scores per sample in tumor tissues and adjacent normal tissues was shown in Figure 1F, the rate of STC-1 protein high/moderate expression in ESCC and normal tissues was $65.9 \%(56 / 85)$ and $7.1 \%(6 / 85)$, respectively, which showed a significant difference $(P<0.001)$.

\section{STC-1 mRNA expression profiles in PB and BM from ESCC} patients

The frequencies of STC-1 mRNA expression detected in $\mathrm{PB}$ and $\mathrm{BM}$ were $37.6 \%(32 / 85)$ and $21.2 \%(18 / 85)$, respectively, and showed no correlations with each other $(P>0.05)$, their combination increased the sensitivity to 48.2\% (41/85) (Table 2). STC-1 mRNA detected in PB
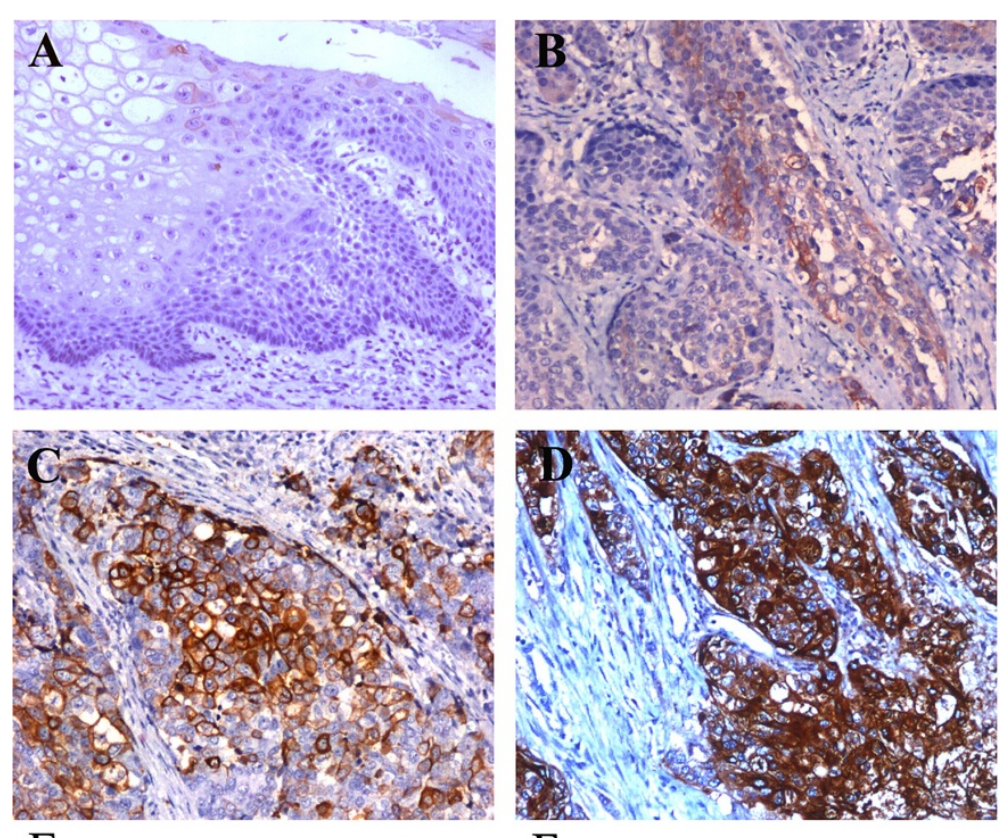

$\mathrm{E}$

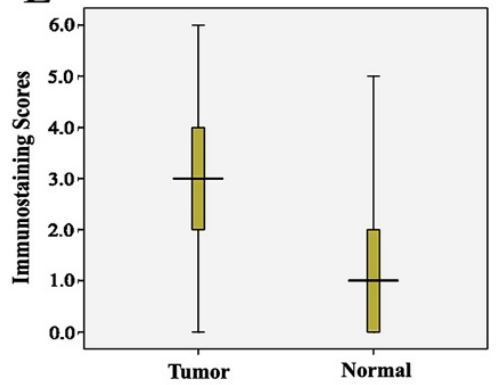

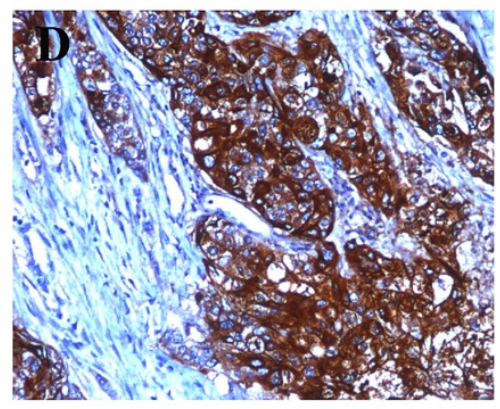

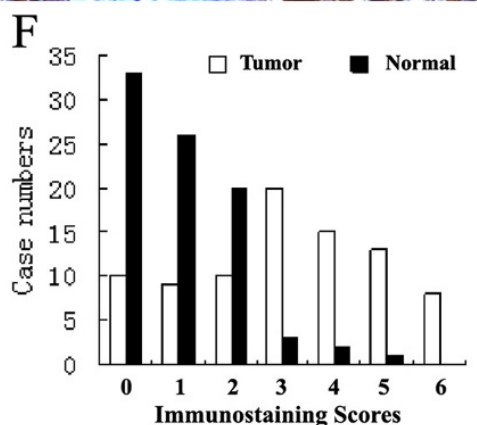

Figure 1 STC-1 protein expression in ESCC and matched normal tissues determined by immunohistochemical staining (magnification $\times$ 200). (A) STC-1 negative in normal tissue; (B) low STC-1 expression in tumor tissue; (C) moderate STC-1 expression in tumor tissue; (D) high STC-1 expression in tumor tissue. (E) The average immunostaining scores of STC-1 expression in tumor and normal tissues; (F) Distribution of immunostaining scores per sample in tumor and adjacent normal tissues. 
and/or BM was closely associated with its protein high/ moderate expression in parallel tumor tissues, regardless of clinical staging (Table 3). Furthermore, in the $40 \mathrm{~PB}$ and/or BM samples from patients with benign esophageal disease, only 2 cases (5.0\%) were found to be STC-1 mRNA-positive, this frequency was remarkably lower than that in the cancer patients $(P<0.001)$. Figure 2 shows the typical PCR results.

\section{Association between STC-1 mRNA expression and clinicopathological features}

As shown in Table 4, STC-1 mRNA expression in PB and BM of ESCC patients were both associated with lymph metastasis and clinical stage. However, there were no correlations of STC-1 mRNA expression and patients' gender, age, tumor site, depth and cellular differentiation.

\section{Association between STC-1 mRNA expression and ESCC prognosis}

To the follow-up deadline, there were 39 patients with progression or relapse within 2 years after the end of surgery. We performed univariate survival analyses to investigate the possible prognostic role of STC-1 expression in ESCC. As shown in Figure 3, the STC-1 expression in $\mathrm{PB}$ and $\mathrm{BM}$ were both associated with poor 2-year PFS (mean 16.2 months (95\%CI: 13.688-18.750) vs 20.2 months (95\%CI: 18.677-21.738), $P=0.009$, and mean 15.0 months (95\%CI: 11.543-18.457) vs 19.7 months (95\%CI: 18.264-21.139), $P=0.003$, respectively). Also in combination, patients with STC-1 mRNA expression in PB and/or BM showed a shortened PFS, as compared to that with STC-1 negative expression (mean 16.7 months

Table 2 STC-1 mRNA expression in peripheral blood and bone marrow of ESCC patients $(n=85)$

\begin{tabular}{cccc}
\hline $\begin{array}{c}\text { peripheral } \\
\text { blood }\end{array}$ & STC-1 & \multicolumn{2}{c}{ bone marrow } \\
$(+)$ & STC-1 (-) & P-value \\
\hline STC-1 (+) & 9 & 23 & 0.223 \\
STC-1 (-) & 9 & 44 & \\
\hline
\end{tabular}

$(+)$, positive; (-), negative.

Table 3 Correlation of STC-1 expression in ESCC tissue and peripheral blood/bone marrow $(n=85)$

\begin{tabular}{lccc}
\hline $\begin{array}{l}\text { Protein expression } \\
\text { in ESCC tissue }\end{array}$ & \multicolumn{2}{c}{ peripheral blood /bone marrow } & \\
\cline { 2 - 3 } STC-1 & mRNA (+) STC-1 mRNA (-) & $P$-value \\
\hline Stage I/II & 11 & 11 & 0.012 \\
STC-1 high/moderate & 3 & 18 & \\
STC-1 low/negative & & & \\
Stage III/IV & 24 & 7 & 0.008 \\
STC-1 high/moderate & 3 & 8 & \\
STC-1 low/negative & 3 & & \\
\hline
\end{tabular}

$(+)$, positive; (-), negative.

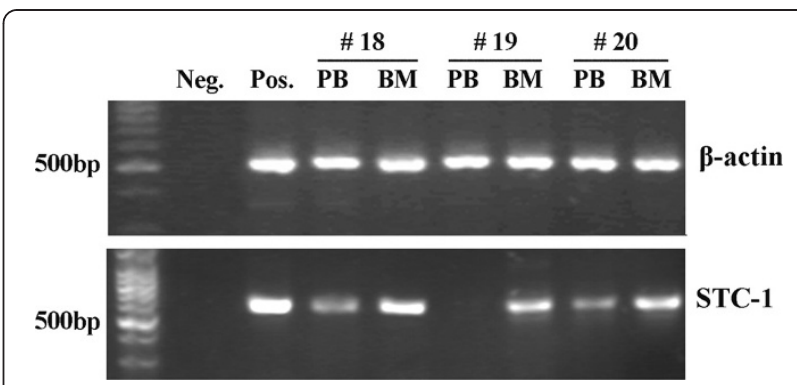

Figure 2 Profiles of STC-1 mRNA expression in the peripheral blood (PB) and bone marrow (BM) of three ESCC patients. Neg, a water blank was used as the negative control; Pos, a resected ESCC tumor tissue was used as the positive control.

(95\%CI: 14.461-18.905) vs 20.6 months (95\%CI: 19.01422.167), $P=0.005)$.

Furthermore, multiple Cox regression analysis was used to verify whether the investigated variables including STC-1 expression were valid predictors of outcome after adjusting for potential confounding cofactors.

Table 4 Association between STC-1 expression and clinicopathological features

\begin{tabular}{|c|c|c|c|c|c|}
\hline Characteristics & No. & $\begin{array}{c}\text { peripheral } \\
\text { STC-1 (+) (\%) }\end{array}$ & $\frac{\text { blood }}{P \text {-value }}$ & STC-1 (+) (\%) & $\frac{\text { rrow }}{P \text {-value }}$ \\
\hline Gender & & & 0.674 & & 0.429 \\
\hline Male & 54 & 19(35.2\%) & & 10(18.5\%) & \\
\hline Female & 31 & 13(41.9\%) & & $8(25.8 \%)$ & \\
\hline Age & & & 0.242 & & 0.446 \\
\hline$<60$ & 35 & $11(31.4 \%)$ & & $6(17.1 \%)$ & \\
\hline$\geq 60$ & 50 & $22(44.0 \%)$ & & $12(24.0 \%)$ & \\
\hline Tumor site & & & 0.632 & & 0.547 \\
\hline Upper thoracic & 17 & $5(29.4 \%)$ & & $4(23.5 \%)$ & \\
\hline Middle thoracic & 33 & 12 (36.4\%) & & $5(15.2 \%)$ & \\
\hline Lower thoracic & 35 & 15 (42.9\%) & & $9(25.7 \%)$ & \\
\hline Differentiation & & & 0.615 & & 0.575 \\
\hline Well & 18 & $5(27.8 \%)$ & & $3(16.7 \%)$ & \\
\hline Moderate & 38 & $15(39.5 \%)$ & & 7 (18.4\%) & \\
\hline Poor & 29 & $12(41.4 \%)$ & & $8(27.6 \%)$ & \\
\hline T status & & & 0.583 & & 0.329 \\
\hline $\mathrm{T} 1 \sim 2$ & 51 & $18(35.3 \%)$ & & $9(17.6 \%)$ & \\
\hline $\mathrm{T} 3 \sim 4$ & 34 & $14(41.2 \%)$ & & $9(26.5 \%)$ & \\
\hline Lymph metastasis & & & $0.000^{*}$ & & $0.013^{*}$ \\
\hline $\mathrm{N}_{0}$ & 41 & $7(17.1 \%)$ & & $4(9.76 \%)$ & \\
\hline $\mathrm{N}_{1} / \mathrm{N}_{2} / \mathrm{N}_{3}$ & 44 & $25(56.8 \%)$ & & 14(31.8\%) & \\
\hline Clinical stage & & & $0.020^{*}$ & & $0.029^{*}$ \\
\hline$|/| \mid$ & 43 & $11(25.6 \%)$ & 23 & $5(11.6 \%)$ & 20 \\
\hline III/IV & 42 & $21(50.0 \%)$ & 33 & 13(31.0\%) & 9 \\
\hline
\end{tabular}




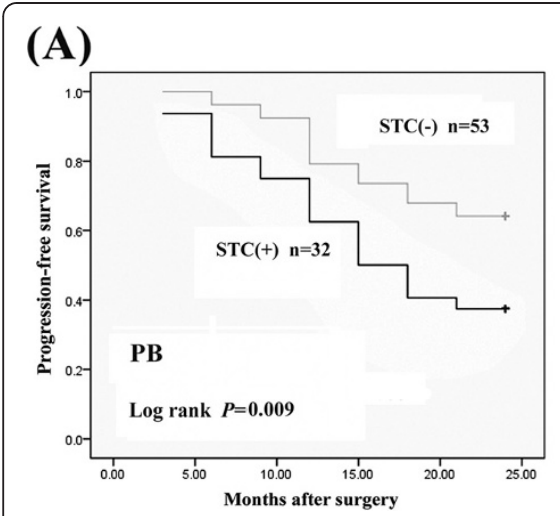

(B)

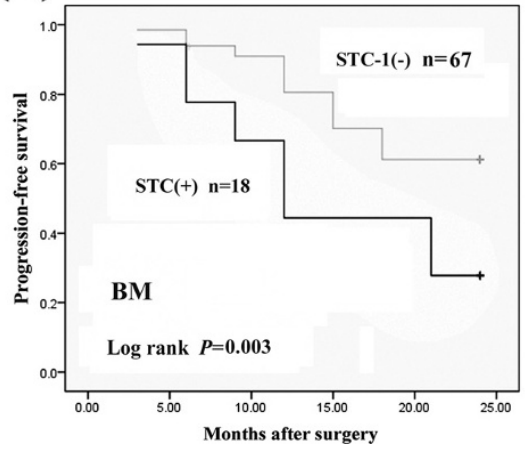

(C)

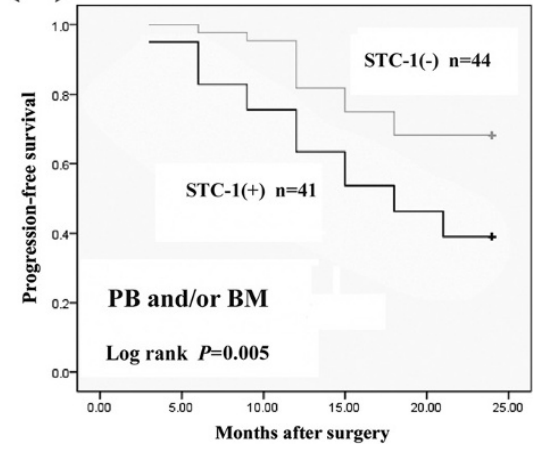

Figure 3 Correlation between STC-1 mRNA expression in (A) peripheral blood (PB), (B) bone marrow (BM), and (C) PB and/or BM with 2-year progression-free survival among 85 ESCC patients using Kaplan-Meier statistical analyses. (+), positive; $(-)$, negative

Results showed that STC-1 expression in PB and/or BM, apart from lymph metastasis and advanced stage, were independent factors for predicting an adverse 2-year PFS for ESCC patients (Table 5).

\section{Discussion}

Hematogenous metastasis is the main cause of the poor outcomes for cancer patients, and there are many previous studies of DTCs that detach from the primary tumor, enter the bloodstream and travel via circulation to distant sites [12,13]. However, the relationships between BM micrometastases (BMM) and clinical outcome of ESCC are relatively insufficient [14]. BM is a major site for tumor cell deposition and dissemination. Evidences have shown that tumor cells spread into the BM while the primary tumor is still in the early stages, and BM acts as an intermediate site for target organ metastasis. Studies of BM samples by various methods have indicated that the presence or absence of BMM is associated with the clinical outcome of patients with esophageal carcinoma $[15,16]$. We currently investigated the DTCs

Table 5 Multivariate analysis of clinicopathological factors for $\mathbf{2}$ year progression-free survival (PFS) of $\mathbf{8 5}$ patients with ESCC

\begin{tabular}{llll}
\hline Characteristics & Category & RR $(\mathbf{9 5 \%} \mathbf{C l})$ & $\boldsymbol{P}$-value \\
\hline Age & $\geq 60$ vs $<60$ years & $1.500(0.626-3.596)$ & 0.363 \\
Tumor differentiation & Poor vs Well/Moderate & $1.607(0.658-3.925)$ & 0.296 \\
T status & $\mathrm{T} 3 \sim 4$ vs T1 2 & $1.963(0.814-4.733)$ & 0.131 \\
Lymph metastasis & $\mathrm{N}_{1} / \mathrm{N}_{2} / \mathrm{N}_{3}$ Vs $\mathrm{N}_{0}$ & $3.111(1.276-7.583)$ & $0.011^{*}$ \\
Clinical stage & III/IV vs I/II & $3.046(1.255-7.395)$ & $0.013^{*}$ \\
STC-1 expression & Positive vs Negtive & $3.348(1.372-8.172)$ & $0.007^{*}$ \\
in PB and/or BM & & & \\
KPS scores & $\geq 90$ vs $<90$ & $0.691(0.281-1.703)$ & 0.422
\end{tabular}

RR: Relative risk; PB: peripheral blood; BM: bone marrow; KPS: Karnofsky performance status.

${ }^{*} P<0.05$. in $\mathrm{PB}$ and BM by nested RT-PCR, to further confirm their clinical significance in ESCC.

Because PB and BM are mesenchymal tissues that do not normally express epithelial cell markers, detection of the expression of specific epithelial markers in the $\mathrm{PB}$ and BM implies the presence of metastatic cancer cells. Although many epithelial markers have been used previously, such as carcinoma embryonic antigen, cytokeratins and survivin, it is important to identify new potential biomarkers $[14,15,17]$. STC-1 is a kind of glycoprotein hormone, first found in bony fish and later in humans and mammals, with a highly conserved homology. Its primary function in fish is prevention of hypercalcemia and stimulation of phosphate reabsorption [18]. In mammals, STC-1 appears to play multiple roles in a series of biological processes, including pregnancy, lactation, angiogenesis, cerebral ischemia, oxidative stress and apoptosis [19-22]. Moreover, there is growing evidences suggesting that STC-1 is involved in carcinogenesis [23]. STC-1 expression levels are universally much higher in tumor tissues and cancer cell lines, such as hepatocellular, colorectal, ovarian, breast cancer and medullary thyroid cancer, than those in corresponding normal tissues [7,24-29]. Recently, Shirakawa et al [8] found that STC-1 mRNA and protein are overexpressed in ESCC tumors, compared with those in corresponding normal tissues, which significantly correlates with an advanced $\mathrm{T}$ status and poor prognosis for ESCC patients. This observation suggests that STC-1 may be useful as a tumor marker for ESCC. In fact, use of the STC-1 expression level as a diagnostic or prognostic biomarker in the blood has been validated in breast, lung, colorectal cancer, as well as hepatocellular carcinoma and leukemia [11,25,30-33]. The detection of STC-1 mRNA in BM has also been reported in breast cancer, which correlates with multiple histopathological prognostic factors, including primary tumor size, the number of positive lymph nodes and TNM stage [33]. 
In concordance with previous studies, we found that the level of STC-1 protein expression in ESCC was much higher than that in matched normal tissues, which further confirmed STC-1 as a promising tumor marker for ESCC. Moreover, STC-1 mRNA detection in PB and $\mathrm{BM}$ showed good sensitivity and specificity, the frequencies in $\mathrm{PB}$ and $\mathrm{BM}$ were $37.6 \%$ and $21.2 \%$, respectively, which was comparable with other epithelial markers reported in ESCC. A previous study has indicated that DTCs detected in PB of breast cancer could not be an alternative to detect it in BM, because there are some different characters with each other [34]. We also found that DTCs detected in $\mathrm{PB} / \mathrm{BM}$ had no correlations with each other, and together increased the sensitivity to $48.2 \%$, which was much higher than that in controls with benign esophageal disease, and DTCs detected in PB and BM of ESCC patients were both associated with lymph metastasis, clinical stage and adverse prognosis. These results indicated that, DTC detection in PB is a non-invasive and more convenient method, but cannot replace that in $\mathrm{BM}$, their combination will contribute to improve the test efficacy, and maybe useful as a diagnostic or prognositc biomarker.

Currently, the most important conventional prognostic factors for ESCC are the lesion length, invasion depth and lymph metastasis at the time of diagnosis (pTNM), which largely determines the treatment plan. However, the actual outcome of the disease is not entirely consistent with these clinicopathological parameters. Some patients at an early stage suffer tumor recurrence or metastasis soon after initial treatment, and others at advanced stages have long-term survival $[35,36]$, which maybe due to the different molecular biology characteristics of their tumors, and DTC status may play an important role. A frequently updated pTNM still fails to discriminate between degrees of malignancy. Thus, in addition to these clinicopathological parameters, molecular markers are being sought in ESCC, and DTC dection has shown a promising prospect. Our study confirmed that DTC detected either in PB or BM of ESCC patients, which was represented by STC-1 mRNA expression, were both associated with an adverse 2 year PFS. These results were further verified with a Cox proportional hazard model, in which STC-1 mRNA expression in PB and/or BM from ESCC patients was found to be an independent unfavorable prognostic factor, apart from regional lymph metastasis and advanced stage. This suggests that DTC status may be a key factor determing the ESCC outcome. Thus, if a patient is found to be DTC-positive, comprehensive treatment including adjuvant radiochemotherapy should be recommended, which may improve patient survival by eliminating the DTCs and suppressing the micrometastasis.

\section{Conclusions}

In this study, we performed nested RT-PCR to detect a potential representative biomarker of DTCs, STC-1 mRNA expression in $\mathrm{PB}$ and $\mathrm{BM}$ from ESCC patients. We found that STC-1 mRNA expression is a reliable marker to detect DTCs, and DTC positivity may be a promising indicator for diagnostic and prognostic assessment of ESCC.

\section{Abbreviations}

BM: Bone marrow; DTCs: Disseminated tumor cells; ESCC: Esophageal squamous cell carcinoma; PB: Peripheral blood; PBMNCs: Peripheral blood mononuclear cells; PFS: Progression-free survival; RT-PCR: Reversetranscriptase polymerase chain reaction; STC-1: Stanniocalcin-1.

\section{Competing interests}

The authors declare that they have no competing interests.

\section{Acknowledgements}

Our study would not have been possible without the participation of the patients. The valuable help from the Department of Gastroenterology of Jinling Hospital for sample collection was greatly appreciated.

\section{Author details}

'Department of Medical Oncology, Jinling Hospital, 305 East Zhongshan Road, Nanjing, 210002, P.R. China. ${ }^{2}$ Department of Cardiothoracic Surgery, Jinling Hospital, 305 East Zhongshan Road, Nanjing, 210002, P.R. China.

\section{Authors' contributions}

JY and HS designed the study. HS performed Nest RT-PCR. BX participated in the sample collection and performed the statistical analysis. HS drafted the manuscript. HS and JY revised the manuscript. All authors read and approved the final manuscript.

Received: 20 January 2012 Accepted: 26 April 2012

Published: 26 April 2012

\section{References}

1. Zheng S, Vuitton L, Sheyhidin I, Vuitton DA, Zhang Y, Lu X: Northwestern China: a place to learn more on oesophageal cancer. Part one: behavioural and environmental risk factors. Eur I Gastroenterol Hepatol 2010, 22:917-925.

2. Lordick F, Ebert M, Stein HJ: Current treatment approach to locally advanced esophageal cancer: is resection mandatory? Future Oncol 2006, 2:717-721.

3. Riethdorf S, Wikman H, Pantel K: Review: biological relevance of disseminated tumor cells in cancer patients. Int J Cancer 2008, 123:1991-2006.

4. Lin H, Balic M, Zheng S, Datar R, Cote RJ: Disseminated and circulating tumor cells: role in effective cancer management. Crit Rev Oncol Hematol 2011, 77:1-11

5. Sun YF, Yang XR, Zhou J, Qiu SJ, Fan J, Xu Y: Circulating tumor cells: advances in detection methods, biological issues, and clinical relevance. J Cancer Res Clin Oncol 2011, 137:1151-1173.

6. Koide Y, Sasaki T: Stanniocalcin-1 (STC-1) as a molecular marker for human cancer. Rinsho Byori 2006, 54:213-220.

7. Tamura S, Oshima T, Yoshihara K, Kanazawa A, Yamada T, Inagaki D, Sato T, Yamamoto N, Shiozawa M, Morinaga S, Akaike M, Kunisaki C, Tanaka K, Masuda M, Imada T: Clinical significance of STC1 gene expression in patients with colorectal cancer. Anticancer Res 2011, 31:325-329.

8. Shirakawa M, Fujiwara Y, Sugita Y, Moon JH, Takiguchi S, Nakajim K, Miyata $H$, Yamasaki M, Mori M, Doki Y: Assessment of stanniocalcin-1 as a prognostic marker in human esophageal squamous cell carcinoma. Oncol Rep 2012, 27:940-946.

9. Rice TW, Blackstone EH, Rusch WW: 7th edition of the AJCC Cancer Staging Manual: esophagus and esophagogastric junction. Ann Surg Oncol 2010, $17: 1721-1724$ 
10. Tong JD, Jiao NL, Wang YX, Zhang YW, Han F: Downregulation of fibulin-3 gene by promoter methylation in colorectal cancer predicts adverse prognosis. Neoplasma 2011, 58:441-448

11. Tohmiya $Y$, Koide $Y$, Fujimaki S, Harigae H, Funato T, Kaku M, Ishii T, Munakata Y, Kameoka J, Sasaki T: Stanniocalcin-1 as a novel marker to detect minimal residual disease of human leukemia. Tohoku J Exp Med 2004, 204:125-133.

12. Liu Z, Jiang $M$, Zhao J, Ju H: Circulating tumor cells in perioperative esophageal cancer patients: quantitative assay system and potential clinical utility. Clin Cancer Res 2007, 13:2992-2997.

13. Wang L, Wang Y, Liu Y, Cheng M, Wu X, Wei H: Flow cytometric analysis of CK19 expression in the peripheral blood of breast carcinoma patients: relevance for circulating tumor cell detection. J Exp Clin Cancer Res 2009, 28:57.

14. Zhang X, Chen SB, Chen JX, Wen J, Yang H, Xie MR, Zhang Y, Hu YZ, Lin P: CK19 mRNA expression in the bone marrow of patients with esophageal squamous cell carcinoma and its clinical significance. Dis Esophagus 2010, 23:437-443.

15. Natsugoe S, Nakashima S, Nakajo A, Matsumoto M, Okumura H, Tokuda K, Miyazono F, Kijima F, Aridome K, Ishigami S, Takao S, Aikou T: Bone marrow micrometastasis detected by RT-PCR in esophageal squamous cell carcinoma. Oncol Rep 2003, 10:1879-1883.

16. Thorban S, Roder JD, Nekarda H, Funk A, Siewert JR, Pantel K: Immunocytochemical detection of disseminated tumor cells in the bone marrow of patients with esophagea carcinoma. J Natl Cancer Inst 1996, 88:1222-1227

17. Cao M, Yie SM, Wu SM, Chen S, Lou B, He X, Ye SR, Xie K, Rao L, Gao E, Ye $N Y$ : Detection of survivin-expressing circulating cancer cells in the peripheral blood of patients with esophageal squamous cell carcinoma and its clinical significance. Clin Exp Metastasis 2009, 26:751-758.

18. Wagner GF, Jaworski EM, Haddad M: Stanniocalcin in the seawater salmon: structure, function, and regulation. Am J Physiol 1998, 274: R1177-R1185.

19. Deol HK, Varghese R, Wagner GF, Dimattia GE: Dynamic regulation of mouse ovarian stanniocalcin expression during gestation and lactation. Endocrinology 2000, 141:3412-3421.

20. Zhang K, Lindsberg PJ, Tatlisumak T, Kaste M, Olsen HS, Andersson LC: Stanniocalcin: a molecular guard of neurons during cerebral ischemia. Proc Natl Acad Sci USA 2000, 97:3637-3642.

21. Nguyen A, Chang AC, Reddel RR: Stanniocalcin-1 acts in a negative feedback loop in the prosurvival ERK1/2 signaling pathway during oxidative stress. Oncogene 2009, 28:1982-1992.

22. He LF, Wang TT, Gao QY, Zhao GF, Huang YH, Yu LK, Hou YY: Stanniocalcin1 promotes tumor angiogenesis through up-regulation of VEGF in gastric cancer cells. J Biomed Sci 2011, 18:39.

23. Chang AC, Jellinek DA, Reddel RR: Mammalian stanniocalcins and cancer. Endocr Relat Cancer 2003, 10:359-373.

24. Okabe H, Satoh S, Kato T, Kitahara O, Yanagawa R, Yamaoka Y, Tsunoda T, Furukawa $Y$, Nakamura $Y$ : Genome-wide analysis of gene expression in human hepatocellular carcinomas using CDNA microarray: identification of genes involved in viral carcinogenesis and tumor progression. Cancer Res 2001, 61:2129-2137.

25. Fujiwara $Y$, Sugita $Y$, Nakamori S, Miyamoto A, Shiozaki K, Nagano H, Sakon M, Monden M: Assessment of Stanniocalcin-1 mRNA as a molecular marker for micrometastases of various human cancers. Int J Oncol 2000, 16:799-804.

26. Macartney-Coxson DP, Hood KA, Shi HJ, Ward T, Wiles A, O'Connor R, Hall DA, Lea RA, Royds JA, Stubbs RS, Rooker S: Metastatic susceptibility locus, an $8 p$ hot-spot for tumour progression disrupted in colorectal liver metastases: 13 candidate genes examined at the DNA, mRNA and protein level. BMC Cancer 2008, 8:187.

27. Liu G, Yang G, Chang B, Mercado-Uribe I, Huang M, Zheng J, Bast RC, Lin SH, Liu J: Stanniocalcin 1 and ovarian tumorigenesis. J Natl Cancer Inst 2010, 102:812-827

28. McCudden CR, Majewski A, Chakrabarti S, Wagner GF: Co-localization of stanniocalcin-1 ligand and receptor in human breast carcinomas. Mol Cell Endocrinol 2004, 213:167-172.

29. Watanabe T, Ichihara M, Hashimoto M, Shimono K, Shimoyama Y, Nagasaka T, Murakumo Y, Murakami H, Sugiura H, Iwata H, Ishiguro N, Takahashi M: Characterization of gene expression induced by RET with MEN2A or MEN2B mutation. Am J Pathol 2002, 161:249-256.
30. Du YZ, Gu XH, Li L, Gao F: The diagnostic value of circulating stanniocalcin-1 mRNA in non-small cell lung cancer. J Surg Oncol 2011 104:836-840.

31. Wu PP, Wu P, Huang PL, Long QQ, Bu XD: Stanniocalcin-1 detection of peripheral blood in patients with colorectal cancer. Chin J Cancer Res 2010, 22:274-279.

32. Nakagawa T, Martinez SR, Goto Y, Koyanagi K, Kitago M, Shingai T, Elashoff $D A$, Ye $X$, Singer FR, Giuliano AE, Hoon DS: Detection of circulating tumor cells in early-stage breast cancer metastasis to axillary lymph nodes. Clin Cancer Res 2007, 13:4105-4110.

33. Wascher RA, Huynh KT, Giuliano AE, Hansen NM, Singer FR, Elashoff D, Hoon DS: Stanniocalcin-1: a novel molecular blood and bone marrow marker for human breast cancer. Clin Cancer Res 2003, 9:1427-1435.

34. Fehm T, Hoffmann O, Aktas B, Becker S, Solomayer EF, Wallwiener D, Kimmig R, Kasimir-Bauer S: Detection and characterization of circulating tumor cells in blood of primary breast cancer patients by RT-PCR and comparison to status of bone marrow disseminated cells. Breast Cancer Res 2009, 11:R59.

35. Gertler R, Stein HJ, Langer R, Nettelmann M, Schuster T, Hoefler $H$, Siewert $J R$, Feith M: Long-term outcome of 2920 patients with cancers of the esophagus and esophagogastric junction: evaluation of the New Union Internationale Contre le Cancer/American Joint Cancer Committee staging system. Ann Surg 2011, 253:689-698.

36. Okamura S, Fujiwara H, Shiozaki A, Komatsu S, Ichikawa D, Okamoto K Murayama Y, Ikoma H, Kuriu Y, Nakanishi M, Ochiai T, Kokuba Y, Sonoyama T, Otsuji E: Long-term survivors of esophageal carcinoma with distant lymph node metastasis. Hepatogastroenterology 2011, 58:421-425.

doi:10.1186/1756-9966-31-35

Cite this article as: Song et al:

Clinical significance of stanniocalcin-1 detected in peripheral blood and bone marrow of esophageal squamous cell carcinoma patients. Journal of Experimental \& Clinical Cancer Research 2012 31:

\section{Submit your next manuscript to BioMed Central and take full advantage of:}

- Convenient online submission

- Thorough peer review

- No space constraints or color figure charges

- Immediate publication on acceptance

- Inclusion in PubMed, CAS, Scopus and Google Scholar

- Research which is freely available for redistribution 